\title{
FORMULATION AND IN VITRO EVALUATION OF BILAYER TABLET OF ATENOLOL FOR BIPHASIC DRUG RELEASE
}

\author{
TARUN PARASHAR*, NARDEV SINGH
}

Department of Pharmaceutics, Uttaranchal Institute of Pharmaceutical Sciences, Dehradun, Uttarakhand, India. Email: parashar89tarun@gmail.com

Received: 07 October 2017, Revised and Accepted: 20 January 2018

\begin{abstract}
Objective: In the present research work, the aim was to prepare the bilayer tablet of atenolol for biphasic drug release to improve its bioavailability and absorption in the lower gastrointestinal tract.

Methods: In the formulation of immediate release crospovidone, croscarmellose sodium, and sodium starch glycolate was used as super disintegrate and was directly compressed. For a sustained release portion different grade hydroxypropyl methylcellulose (HPMC) K4M, HPMC K15M, gum tragacanth, gum acacia, guar gum, and ethyl cellulose. Preformulation studies were performed before compression. The compressed bilayer tablets were evaluated for weight variation, dimension, hardness, friability, drug content, disintegration time, and in vitro drug release using USP dissolution apparatus type 2 (paddle).

Results: The formulation IR3 showed 95\% drug release in $30 \mathrm{~min}$, and regression coefficient value ( $\mathrm{r}^{2}$ ) value was found to be 0.994 suggesting first-order drug release kinetics. The F9 formulation using HPMC K15M and gum acacia (1:1) showed 91.20\% drug release at the end of 12 h, and regression coefficient value $\left(\mathrm{r}^{2}\right)$ was 0.992 suggesting zero-order drug release kinetics. Formulation IR3F9 showed faster drug release for bilayer tablet containing 5\%w/w crospovidone in immediate release layer and HPMC and guar gum (1:1) in sustained release. Formulation IR3F9 showed swelling index $206 \%$, floating lag time was found to be $2 \mathrm{~min}$ and total floating time up to $12 \mathrm{~h}$.
\end{abstract}

Conclusion: The formulation IR3F9 showed a faster drug release profile among the others in the preparation of the atenolol bilayer tablet. Hence, it was considered as an optimized formulation.

Keyword: Bilayer tablet, Atenolol, Biphasic drug release, Swelling index.

(C) 2018 The Authors. Published by Innovare Academic Sciences Pvt Ltd. This is an open access article under the CC BY license (http://creativecommons. org/licenses/by/4. 0/) DOI: http://dx.doi.org/10.22159/ajpcr.2018.v11i5.22975

\section{INTRODUCTION}

Oral drug delivery route is the most preferable route of drug delivery. It is due to the various advantages of this route such as ease of administration, patient compliance, and flexibility in the formulations. Oral absorption of drugs is often limited due to short gastric retention time. The gastric retention time is $3-4 \mathrm{~h}$ of human beings. The retention of drug delivery system in the stomach prolongs overall gastrointestinal (GI) transit time, thereby resulting in improved bioavailability drugs. However, oral route has certain problems such as unpredictable gastric emptying rate, the short GI transit time and the existence of an absorption window in the gastric and upper small intestine for several drugs. The bilayer tablet effect of atenolol was always greater than the matrix tablet. Using immediate release dosage disintegrates rapidly and get dissolved to release the medicaments form the therapeutically effective concentration can be maintained for a shorter time and controlled the high blood pressure. Using sustained release dosage form the therapeutically effective concentration can be maintained for a longer time than the conventional dosage form. The sustained release dosage form incident of the local and systemic adverse effects can be reduced. Bilayer tablets are preferred when the release profile of the drugs is different from one another [1-3]. Atenolol is a beta blocker used in the treatment of hypertension and angina pectoris. It is incompletely absorbed from the GI tract and has an oral bioavailability of only $50 \%$, while the remaining is excreted unchanged in feces. This is because of its poor absorption in the lower GI tract. Hypertension is not adequately controlled with average doses of any single antihypertensive drug in $30-50 \%$ patients. The half-life of atenolol is $6-7 \mathrm{~h}$; hence, it is a suitable candidate for the design of sustained release drug delivery system. Bilayer tablet is suitable for sequential release of two drugs in combination, separate two incompatible substances and also for sustained release tablet in which one layer is immediate release as an initial dose and the second layer is maintenance dose. The present case $10 \mathrm{mg}$ atenolol has to be released immediately, and the remaining $25 \mathrm{mg}$ of atenolol has to be released in a sustained manner so that therapeutic concentration can be maintained. For the preparation of biphasic release with variable concentrations of super disintegrant in immediate release layer and rate retarding polymer in sustained release layer for adjusting release pattern according to the need of therapy and IP guidelines of atenolol sustained release tablet. In the bilayer tablet, one of the layers was formulated with super disintegrant for immediate drug release while another layer was formulated with the sustained release using a different polymer with a different ratio. The patient compliance when the drug has been used in a sustained release dosage form rather than conventional tablets and immediate release dosage form for the chronic patient of hypertension and angina pectoris [4-6].

\section{MATERIALS AND METHODS}

Materials

Atenolol was a gift sample from Elder Pharmaceutical Ltd., Dehradun. All ingredients used from college laboratory. All chemicals and reagents used were of analytical grade. 


\section{Methods}

Procedure for immediate release layer

All the ingredients were accurately weighed and passed through sieve having a mesh size \# 80. To mix the ingredients thoroughly drug and polymer were blended geometrically in a mortar and pestle for $15 \mathrm{~min}$ then; talc was mixed. After thoroughly mixing these ingredients, the powder blend was passed through mesh size \# 44 .

\section{Procedure for sustained release layer}

All the ingredients were accurately weighed and passed through sieve having a mesh size \# 80. To mix the ingredients thoroughly drug and polymer were blended geometrically in a mortar and pestle for $15 \mathrm{~min}$ then; binder preparation was added in the blended powder formation of the heap and passed through mesh size \# $30[7,8]$.

\section{Compression of bilayer tablet}

In the present study, bilayer tablet of $500 \mathrm{mg}$ weight was prepared manually using the single station punching machine. Accurately weighed amounts of the SR powder mixture were fed manually into the die cavity. SR layer was compressed at mild compression force $\left(2-3 \mathrm{~kg} / \mathrm{cm}^{2}\right)$ after that accurately weighed IR powder mixture was manually fed into the die on SR layer and compressed using $9 \mathrm{~mm}$ circular punches. Both the layers were identified on the basis of color since the immediate release layer had the pink color, and the sustained release layer has white color different formulations were made to achieve the desired drug release from the IR layer and SR layer of the bilayer tablet. The combination of the immediate release layer and sustained release layer for atenolol bilayer matrix tablets shown in Tables 1 and 2 .

\section{RESULTS}

Precompression parameters of immediate release layer and sustained release layer $[9,10]$

The atenolol immediate release layer was evaluated for angle of repose, bulk density, tapped density, Hausner's ratio (HR), and compressibility

Table 1: Combination of immediate release layer for atenolol bilayer matrix tablets

\begin{tabular}{llll}
\hline Formulation code & IR1 & IR2 & IR3 \\
\cline { 1 - 1 } Ingredients (mg) & & & \\
\hline Atenolol & 10 & 10 & 10 \\
MCC PH 102 & 90 & 90 & 90 \\
Lactose & 84 & 84 & 84 \\
CCS & 10 & - & - \\
SSG & - & 10 & - \\
Crospovidone & - & - & 10 \\
Talc & 4 & 4 & 4 \\
Ferric red oxide & 2 & 2 & 2 \\
\hline
\end{tabular}

index. The bulk density was found in the range of 0.391-0.418 g/ $\mathrm{cm}^{3}$. The tapped density was range $0.431-0.486 \mathrm{~g} / \mathrm{cm}^{3}$. The angle of repose varied from $27.42^{\circ}$ to $27.52^{\circ}$. The compressibility index was in the range of $12.43-15.20 \%$. The HR was in the range of 1.152-1.172 shown in Table 3. The atenolol sustained release layer was prepared by the wet granulation method the powder was evaluated for angle of repose, bulk density, tapped density, HR, and compressibility index. The bulk density was found in the range of $0.202-0.486 \mathrm{~g} / \mathrm{cm}^{3}$. The tapped density was range $0.192-0.556 \mathrm{~g} / \mathrm{cm}^{3}$. The angle of repose varied from $27.20^{\circ}$ to $31.40^{\circ}$. The compressibility index was in the range of 5.97-19.84\%. The HR was in the range of 1.063-1.247 and the moisture content of the granules was range $0.43-0.67 \%$ shown in Table 4.

Postcompression parameter of immediate release layer and sustained release layer $[11,12]$

The atenolol immediate release layer postcompression parameter was evaluated for hardness, friability, weight variation, thickness, and disintegration time. The hardness of tablet of each formulation was found in the range of $3.50 \pm 0.200-3.86 \pm 0.124 \mathrm{~kg} / \mathrm{cm}^{2}$. The friability was in the range of $0.20 \%-0.70 \%$. The weight of tablet of each formulation varied from $202 \pm 1.38 \mathrm{mg}$ to $206 \pm 1.44 \mathrm{mg}$. All tablets were within the pharmacopeia limits of the weight. The weight of all tablets was found to be uniform with low standard deviation valve. The thickness of all tablets was founded in the range of $3.90 \pm 0.0054$ $\mathrm{mm}-3.91 \pm 0.0050 \mathrm{~mm}$. The disintegration time of all tablets was found in the range of $4.50 \mathrm{~min}-7.00 \mathrm{~min}$ parameter shown in Table 5. The atenolol sustained release layer postcompression parameter was evaluated for hardness, friability, weight, and thickness. The hardness of tablet of each formulation was found in the range of 4.55 $\pm 0.165-$ $7.13 \pm 0.139 \mathrm{~kg} / \mathrm{cm}^{2}$. The friability was range $0.2 \%-0.60 \%$. The weight of tablet of each formulation in a tablet of each formulation varied from $301 \pm 1.48 \mathrm{mg}$ to $309 \pm 1.38 \mathrm{mg}$ all tablet was within the Indian Pharmacopoeia limits of the weight. The weight of all tablets was found to be uniform with low standard deviation valve. The thickness of all tablets was found in the range of $4.08 \pm 0.0039 \mathrm{~mm}-4.25 \pm 0.0045 \mathrm{~mm}$. The drug content of all tablets was found in the range of $92.34 \pm 1.88 \%$ $98.50 \pm 1.22 \%$. Swelling index and floating studies for sustained release were evaluated. The swelling index of tablet of each formulation was found in the range of $142.92-206.66 \%$. The floating lag time was found in the range of $2 \mathrm{~min}-2.4 \mathrm{~min}$. The floating time of all tablets was found $12 \mathrm{~h}$. The percentage of yield was found in the range of $81-86 \%$ parameter shown in Table 6.

\section{In vitro drug release study [13-17]}

In vitro study was conducted using USP dissolution apparatus II (paddle type).

Dissolution profile for immediate release from IR1 was found $(72 \%$ in $30 \mathrm{~min}$ ) slower than IR2 and IR3. It has $5 \% \mathrm{w} / \mathrm{w}$ croscarmellose sodium used. IR2 formulation showed $84 \%$ drug release in $30 \mathrm{~min}$. It

Table 2: Combination of sustained release layer for atenolol bilayer matrix tablets

\begin{tabular}{|c|c|c|c|c|c|c|c|c|c|c|c|c|}
\hline Code & F 1 & F2 & F3 & F4 & F5 & F6 & F7 & F8 & F9 & F10 & F11 & F12 \\
\hline \multicolumn{13}{|l|}{ Ingredients } \\
\hline Atenolol & 25 & 25 & 25 & 25 & 25 & 25 & 25 & 25 & 25 & 25 & 25 & 25 \\
\hline HPMC K4M & 100 & 125 & 150 & - & - & - & - & - & - & - & - & - \\
\hline HPMC K15M & - & - & - & 154.179 & 173.625 & 115.75 & 154.179 & 173.625 & 115.75 & 154.179 & 173.625 & 115.75 \\
\hline Gum tragacanth & - & - & - & 77.321 & 57.875 & 115.75 & - & - & - & - & - & - \\
\hline Ethyl cellulose & 95 & 70 & 45 & - & - & - & - & - & - & - & - & \\
\hline Gum acacia & - & - & - & - & - & - & 77.321 & 57.875 & 115.75 & - & - & - \\
\hline Guar gum & - & - & - & - & - & - & - & - & - & 77.321 & 57.875 & 115.75 \\
\hline Sod.Bi-carbonate & 35 & 35 & 35 & 9 & 9 & 9 & 9 & 9 & 9 & 9 & 9 & 9 \\
\hline Citric acid & 20 & 20 & 20 & - & - & - & - & - & - & - & - & - \\
\hline PVP k 30 & 19 & 19 & 19 & 30 & 30 & 30 & 30 & 30 & 30 & 30 & 30 & 30 \\
\hline Mg. stearate & 4 & 4 & 4 & - & - & - & - & - & - & - & - & - \\
\hline Talc & 2 & 2 & 2 & 4.5 & 4.5 & 4.5 & 4.5 & 4.5 & 4.5 & 4.5 & 4.5 & 4.5 \\
\hline
\end{tabular}

HPMC: Hydroxypropyl methylcellulose 
Table 3: Micromeritic properties of precompression immediate release layer

\begin{tabular}{|c|c|c|c|c|c|}
\hline \multirow[t]{2}{*}{ Code } & \multicolumn{5}{|l|}{ Parameter } \\
\hline & Bulk density $\left(\mathrm{g} / \mathrm{cm}^{3}\right)$ & Tapped density $\left(\mathrm{g} / \mathrm{cm}^{3}\right)$ & Hausner's ratio & Compressibility index (\%) & Angle of repose \\
\hline IR1 & $0.391 \pm 0.02$ & $0.461 \pm 0.01$ & $1.152 \pm 0.02$ & $12.43 \% \pm 0.05$ & $27.42^{0} \pm 0.19$ \\
\hline IR3 & $0.418 \pm 0.01$ & $0.486 \pm 0.01$ & $1.172 \pm 0.01$ & $15.20 \% \pm 0.11$ & $27.50^{0} \pm 0.09$ \\
\hline
\end{tabular}

Table 4: Micromeritic properties of precompression sustained release layer

\begin{tabular}{|c|c|c|c|c|c|c|}
\hline \multirow[t]{2}{*}{ Code } & \multicolumn{6}{|l|}{ Parameter } \\
\hline & Bulk density $\left(\mathrm{g} / \mathrm{cm}^{3}\right)$ & Tapped density $\left(\mathrm{g} / \mathrm{cm}^{3}\right)$ & Hausner's ratio & Compressibility index (\%) & Angle of repose $\left(^{\circ}\right)$ & LOD \% \\
\hline F1 & 0.486 & 0.556 & 1.219 & 12.589 & $27.40^{\circ}$ & 0.43 \\
\hline F3 & 0.423 & 0.470 & 1.111 & 10.00 & $26.50^{\circ}$ & 0.50 \\
\hline $\mathrm{F} 4$ & 0.203 & 0.241 & 1.187 & 15.76 & $27.60^{\circ}$ & 0.53 \\
\hline F5 & 0.213 & 0.238 & 1.117 & 10.504 & $26.80^{\circ}$ & 0.55 \\
\hline F6 & 0.164 & 0.192 & 1.170 & 14.55 & $27.52^{\circ}$ & 0.51 \\
\hline F7 & 0.177 & 0.214 & 1.120 & 17.28 & $28.20^{\circ}$ & 0.54 \\
\hline F8 & 0.236 & 0.281 & 1.190 & 16.014 & $27.80^{\circ}$ & 0.54 \\
\hline F9 & 0.202 & 0.232 & 1.148 & 12.931 & $27.40^{\circ}$ & 0.56 \\
\hline F10 & 0.187 & 0.200 & 1.069 & 6.50 & $31.10^{\circ}$ & 0.55 \\
\hline F11 & 0.189 & 0.201 & 1.063 & 5.97 & $31.40^{\circ}$ & 0.65 \\
\hline F12 & 0.202 & 0.252 & 1.247 & 19.84 & $27.50^{\circ}$ & 0.67 \\
\hline
\end{tabular}

Table 5: Evaluation of atenolol immediate release layer

\begin{tabular}{|c|c|c|c|c|c|}
\hline Formulation code & $\begin{array}{r}\text { Hardness } \\
\left(\mathrm{kg} / \mathrm{cm}^{2}\right)\end{array}$ & Friability $(\% \mathrm{w} / \mathrm{w})$ & Weight variation (mg) & Thickness (mm) & Disintegration time (min) \\
\hline IR1 & $3.50 \pm 0.200$ & 0.70 & $206 \pm 1.44$ & $3.90 \pm 0.0054$ & 7.00 \\
\hline IR2 & $3.66 \pm 0.180$ & 0.60 & $205 \pm 0.140$ & $3.91 \pm 0.0050$ & 6.30 \\
\hline IR3 & $3.86 \pm 0.124$ & 0.20 & $202 \pm 0.138$ & $3.91 \pm 0.0050$ & 4.50 \\
\hline
\end{tabular}

Table 6: Evaluation of atenolol sustained release layer

\begin{tabular}{|c|c|c|c|c|c|c|c|c|c|}
\hline $\begin{array}{l}\text { Formulation } \\
\text { code }\end{array}$ & $\begin{array}{l}\text { Hardness } \\
\left(\mathrm{kg} / \mathrm{cm}^{2}\right)\end{array}$ & $\begin{array}{l}\text { Friability } \\
(\% w / w)\end{array}$ & $\begin{array}{l}\text { Weight } \\
\text { Variation (mg) }\end{array}$ & $\begin{array}{l}\text { Thickness } \\
\text { (mm) }\end{array}$ & $\begin{array}{l}\text { Drug } \\
\text { Content (\%) }\end{array}$ & $\begin{array}{l}\text { Swelling } \\
\text { index (\%) }\end{array}$ & $\begin{array}{l}\text { Floating lag } \\
\text { time (min) }\end{array}$ & $\begin{array}{l}\text { Floating } \\
\text { time (h) }\end{array}$ & $\begin{array}{l}\text { Percentage } \\
\text { yield }(\%)\end{array}$ \\
\hline F1 & 5.54 & 0.45 & 305 & 4.10 & 95.20 & 146.43 & 2.0 & 12 & 82 \\
\hline $\mathrm{F} 2$ & 5.52 & 0.50 & 301 & 4.18 & 97.10 & 127.06 & 2.0 & 12 & 84 \\
\hline F3 & 4.55 & 0.60 & 301 & 4.20 & 95.23 & 179.66 & 2.0 & 12 & 85 \\
\hline F4 & 6.60 & 0.25 & 303 & 4.22 & 97.40 & 202.77 & 2.1 & 12 & 86 \\
\hline F5 & 5.60 & 0.48 & 302 & 4.25 & 95.67 & 155.70 & 2.5 & 12 & 84 \\
\hline F6 & 6.58 & 0.27 & 308 & 4.10 & 97.12 & 203.33 & 2.3 & 12 & 81 \\
\hline F8 & 4.62 & 0.58 & 308 & 4.14 & 92.42 & 168.65 & 2.4 & 12 & 82 \\
\hline F9 & 6.61 & 0.30 & 309 & 4.08 & 98.75 & 206.00 & 2.2 & 12 & 86 \\
\hline F10 & 6.66 & 0.25 & 306 & 4.17 & 92.34 & 192.43 & 2.3 & 12 & 81 \\
\hline F11 & 6.63 & 0.25 & 307 & 4.11 & 93.14 & 181.67 & 2.2 & 12 & 83 \\
\hline F12 & 7.13 & 0.20 & 308 & 4.08 & 98.50 & 206.66 & 2.0 & 12 & 85 \\
\hline
\end{tabular}

HPMC: Hydroxypropyl methylcellulose

Table 7: Dissolution drug profile of Bilayer formulations

\begin{tabular}{|c|c|c|c|c|c|}
\hline Sl. No. & Time (min) & $\begin{array}{l}\text { Cumulative percentage } \\
\text { drug release (IR3 F4) }\end{array}$ & $\begin{array}{l}\text { Cumulative percentage } \\
\text { drug release (IR3 F6) }\end{array}$ & $\begin{array}{l}\text { Cumulative percentage } \\
\text { drug release (IR3 F9) }\end{array}$ & $\begin{array}{l}\text { Cumulative percentage } \\
\text { drug release (IR3 F12) }\end{array}$ \\
\hline 1 & 15 & 30.23 & 28.56 & 26.62 & 32.46 \\
\hline 2 & 30 & 45.67 & 47.32 & 43.46 & 45.25 \\
\hline 3 & 60 & 52.58 & 55.82 & 54.21 & 57.48 \\
\hline 4 & 120 & 59.80 & 62.81 & 60.38 & 66.56 \\
\hline 5 & 240 & 68.29 & 70.48 & 66.34 & 75.43 \\
\hline 6 & 480 & 76.98 & 78.34 & 72.84 & 83.71 \\
\hline 7 & 960 & 90.12 & 91.11 & 95.23 & 92.81 \\
\hline
\end{tabular}


has $5 \% \mathrm{w} / \mathrm{w}$ sodium starch glycolate used. IR3 formulation showed $95 \%$ drug release in $30 \mathrm{~min}$, and regression coefficient value $\left(\mathrm{r}^{2}\right)$ value was found to be 0.994 . It has $5 \% \mathrm{w} / \mathrm{w}$ crospovidone used comparative in vitro drug release pattern of immediate release layers. The formulation IR3 showed best cumulative drug release. All formulations of immediate release support the first-order kinetics. Therefore, IR3 was selected for further studies.

Dissolution profile for sustained release $\mathrm{F} 1$ to $\mathrm{F} 12$ formulation cumulative drug determine release was up to $12 \mathrm{hrs}$. The F1, F2, and F3 formulation showed $81.98 \%, 83.97 \%$, and $78.29 \%$; cumulative

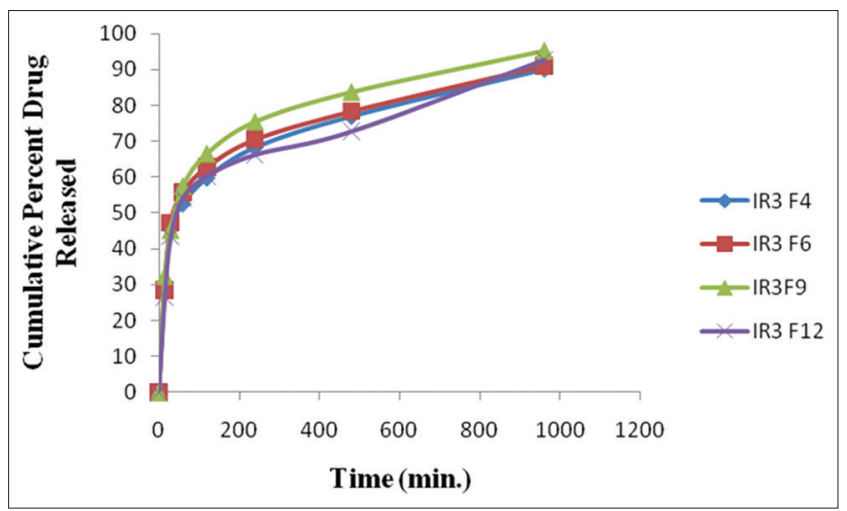

Fig. 1: Cumulative percent drug released versus time plots of formulations IR3 F4, IR3 F6, IR3 F9, and IR3 F12

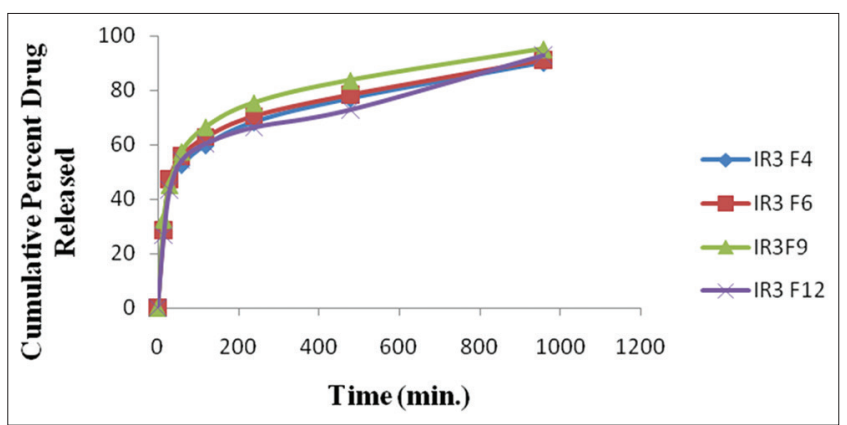

Fig. 2: Cumulative percent drug released versus time plots of formulations IR3 F4, IR3 F6, IR3 F9, and IR3 F12 drug release using hydroxypropyl methylcellulose (HPMC) K4M and ethyl cellulose. The F4, F5, and F6 formulation showed 92.46\%, 79.38\%, and 92.72\%; cumulative drug release using HPMC K15M and gum tragacanth. The formulation F7, F8, and F9 formulations showed 74.14\%, 83.28\%, and 91.20\%; cumulative drug release using HPMC $\mathrm{K} 15 \mathrm{M}$ and gum acacia. The formulation F10, F11, and F12 formulation showed $72.67 \%, 69.19 \%$, and $93.65 \%$; cumulative drug release using HPMC K15M and guar gum. The formulation F4, F6, F9, and F12 showed best cumulative drug release. Therefore F4, F6, F9, and F12 were selected for further studies.

Dissolution profile for bilayer tablet IR3F4, IR3F6, IR3F9, and IR3F12 formulation cumulative drug release showed $90.12 \%, 91.11 \%, 95.23 \%$, and $92.81 \%$ shown in Table 7 and Fig. 1. The formulation cumulative drug release was found up to $12 \mathrm{~h}$. Therefore, IR3F9 was found to be the best formulation among all of them because of its good relationship between cumulative percentage drug releases and time was $95.23 \%$ up to $12 \mathrm{~h}$.

\section{Kinetic release modeling [18-21]}

The release profiles of an immediate release layer of all formulations were compared with zero-order, the first-order model. The data were processed for regression analysis using MS-Excel statistical functions.

The data were evaluated for zero-order, the first-order model, the IR1 to IR3 values obtained were shown in Table 8. The formulation IR3 showed regression coefficient value $\left(\mathrm{r}^{2}\right)$ is 0.994 . The data suggested that release kinetics follow first-order drug release because the values of regression coefficient obtained for first-order release profiles are near to 1 as compared to zero-order.

The release profiles of a sustained release layer of all formulations were compared with zero-order, first-order, Higuchi model, and KorsmeyersPeppas model value shown in Table 9. The cumulative percentage drug release F4, F6, F9, and F12 was higher than other formulation shown in Table 10, Figs. 2 and 3 and regression coefficient value $\left(r^{2}\right) 0.968,0.986$,

Table 8: Kinetic data of immediate release

\begin{tabular}{llll}
\hline Formulation code & Zero-order & First-order & Best fit model \\
\cline { 2 - 3 } & $\mathbf{R}^{\mathbf{2}}$ & $\mathbf{R}^{\mathbf{2}}$ & \\
\hline IR1 & 0.963 & 0.986 & First order \\
IR2 & 0.957 & 0.993 & First order \\
IR3 & 0.930 & 0.994 & First order \\
\hline
\end{tabular}

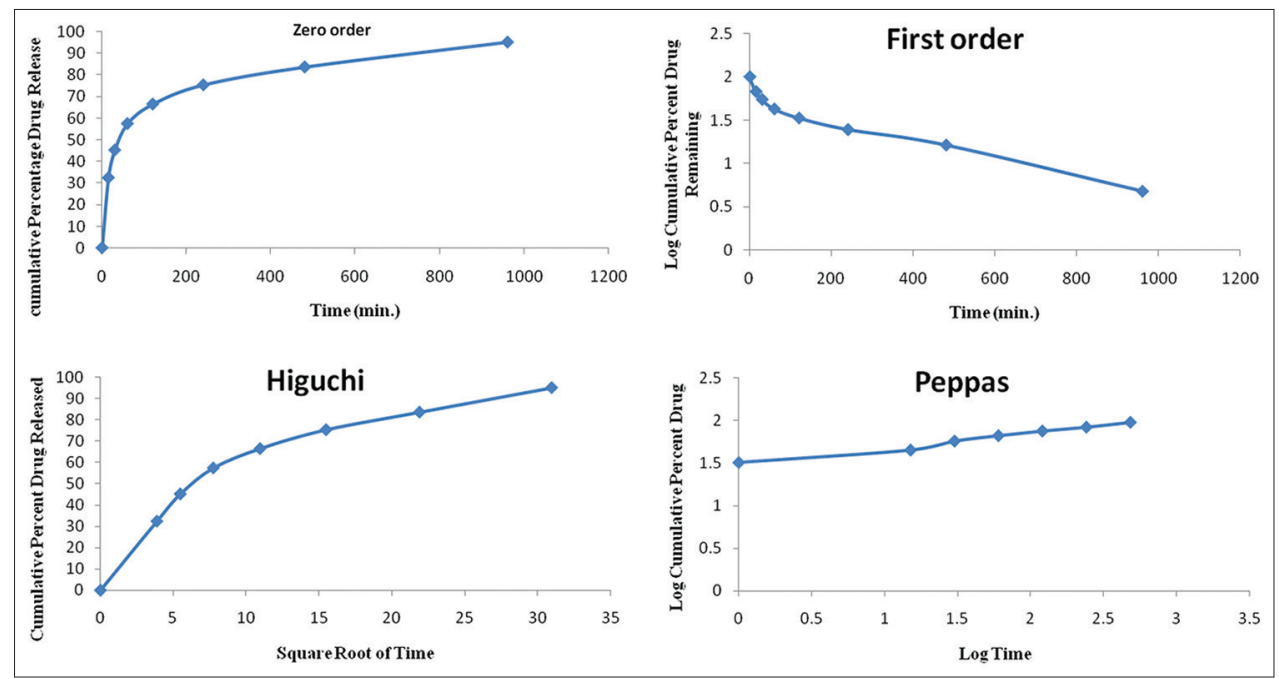

Fig. 3: Release kinetics of optimized formulation IR3F9 
Table 9: Kinetic data of sustained release

\begin{tabular}{|c|c|c|c|c|c|c|}
\hline \multirow[t]{2}{*}{ Formulation code } & \multirow{2}{*}{$\begin{array}{l}\text { Zero-order } \\
\mathbf{R}^{2}\end{array}$} & \multirow{2}{*}{$\begin{array}{l}\text { First-order } \\
\mathbf{R}^{2}\end{array}$} & \multirow{2}{*}{$\begin{array}{l}\text { Higuchi } \\
\mathbf{R}^{2}\end{array}$} & \multicolumn{2}{|c|}{ Peppas } & \multirow[t]{2}{*}{ Best fit model } \\
\hline & & & & $\mathbf{R}^{2}$ & $\mathbf{n}$ & \\
\hline F1 & 0.875 & 0.970 & 0.980 & 0.979 & 0.512 & Higuchi \\
\hline F3 & 0.885 & 0.941 & 0.967 & 0.942 & 0.700 & Higuchi \\
\hline F4 & 0.850 & 0.980 & 0.975 & 0.970 & 0.454 & First \\
\hline F5 & 0.885 & 0.970 & 0.972 & 0.962 & 0.671 & Higuchi \\
\hline F6 & 0.986 & 0.970 & 0.920 & 0.975 & 0.590 & Zero \\
\hline F7 & 0.857 & 0.941 & 0.965 & 0.952 & 0.623 & Higuchi \\
\hline F8 & 0.874 & 0.968 & 0.966 & 0.952 & 0.642 & First \\
\hline F9 & 0.992 & 0.905 & 0.986 & 0.979 & 0.570 & Zero \\
\hline F10 & 0.932 & 0.980 & 0.967 & 0.964 & 0.531 & First \\
\hline F11 & 0.944 & 0.979 & 0.983 & 0.962 & 0.712 & Higuchi \\
\hline F12 & 0.990 & 0.944 & 0.972 & 0.967 & 0.531 & Zero \\
\hline
\end{tabular}

Table 10: In vitro drug release data of bilayer formulations

\begin{tabular}{|c|c|c|c|c|}
\hline Time (min) & $\begin{array}{l}\text { Cumulative percentage } \\
\text { drug release (IR3 F4) }\end{array}$ & $\begin{array}{l}\text { Cumulative percentage } \\
\text { drug release (IR3 F6) }\end{array}$ & $\begin{array}{l}\text { Cumulative percentage } \\
\text { drug release (IR3 F9) }\end{array}$ & $\begin{array}{l}\text { Cumulative percentage } \\
\text { drug release (IR3 F12) }\end{array}$ \\
\hline 15 & 30.23 & 28.56 & 26.62 & 32.46 \\
\hline 30 & 45.67 & 47.32 & 43.46 & 45.25 \\
\hline 60 & 52.58 & 55.82 & 54.21 & 57.48 \\
\hline 120 & 59.80 & 62.81 & 60.38 & 66.56 \\
\hline 240 & 68.29 & 70.48 & 66.34 & 75.43 \\
\hline 480 & 76.98 & 78.34 & 72.84 & 83.71 \\
\hline
\end{tabular}

0.992 , and 0.944 . Moreover, these formulations support the ' $n$ ' value is in the range $0.45-0.60$ also having higher percentage cumulative drug release. After evaluating above parameters, these four formulations were selected for further study.

\section{DISCUSSION}

The drug atenolol was selected for the study because it is nicely fitted in the designed formula and its low bioavailability. Melting point and IR spectra identification results of drug indicate the purity of the drug. IR spectra of pure drug and with the excipients are identical and do not show any incompatibility; thus the excipients are compatible with the drug. Formulation IR3F9 showed flow properties of powder blends. The value of the angle of repose was found to be $27.50^{\circ}$, HR was found to be 1.172 , and compressibility index was found to be $15.20 \%$. The value of angle of repose was found to be $27.40^{\circ}$, HR 1.148 , and compressibility index was found to be $12.93 \%$ indicate good flow properties of powder blends. Friability and hardness were within the pharmacopeial limits thus showing the good mechanical strength of tablets. Formulation IR3F9 showed the drug release for tablet faster release, which contains $5 \% \mathrm{w} / \mathrm{w}$ crospovidone in immediate release layer and sustained release which containing HPMC and guar gum (1:1). Formulation IR3F9 showed the swelling index was found to be $206 \%$, floating lag time was found to be $2 \mathrm{~min}$ and total floating time up to 12 h. Dissolution profile for bilayer tablet IR3F9 formulation a good relation between cumulative drug release and time. The release pattern showed $95.23 \%$ up to $12 \mathrm{~h}$

\section{CONCLUSION}

Atenolol is a $\beta$-adrenoreceptor antagonist or more commonly known as a beta-blocker. It is incompletely absorbed from the GI tract. Bilayer tablet formulation is containing the immediate release and sustained release. In which one layer is formulated to obtain the immediate release of the drug; with the aim of reaching a high serum concentration in a short period of time and the second layer is a controlled release hydrophilic matrix; which is designed to maintain an effective plasma concentration of the drug in the blood for a prolonged period of time which help to decrease the frequency of dosing and also improve the efficacy of drug and patient compliance. Hence, an attempt was made to formulate a bilayer tablet of the antihypertensive drug to diagnose and cure hypertension and angina pectoris for chronic patients.

\section{CONFLICTS OF INTERESTS}

None.

\section{AUTHORS CONTRIBUTION}

Tarun Parashar-Designed the study, developed the methodology, collected the data and performed the analysis and wrote the manuscript.

Nardev singh-contributed in writing the manuscript.

\section{REFERENCES}

1. Jain NK. Progress in Controlled and Novel Drug Delivery System. $3^{\text {rd }}$ ed. New Delhi: CBS Publishers; 2004. p. 67-78.

2. Agyilirah GA, Green M, Ducret R. Evaluation of gastric retention properties of a cross linked polymer coated tablet versus those of a nondisintegrating tablet. Int J Pharm 1991;75:241-5.

3. The United States Pharmacopoeial Convention Inc. USP 27-NF. Rockville, MD: The United States Pharmacopoeial Convention Inc.; 2002. p. $177-80$.

4. British Pharmacopoeia. British Pharmacopoeia Commission. London: British Pharmacopoeia; 1993.

5. Panda AN, Reddy V, Subba Reddy GV, Sultana A. Formulation design and in vitro evaluation of bilayer sustained release matrix tablets of doxofylline. Int J Pharm Pharm Sci 2015;7:74-83.

6. Hardman J, Limbird L, Gilman A. Goodman and Gilman the Pharmacological Basis of Therapeutics. $8^{\text {th }}$ ed. Mcgraw Hill Publications; 1999. p. 249, 256, 861

7. Soniya R, Tarun P, Tyagi S, Patel C, Rishikesh G. Novel oral sustained release technology: A concise review. Int J Res Dev Pharm Life Sci 2013;2:262-9.

8. Lena MT. Preparation and evaluation of atenolol floating beads as a controlled delivery system. Iraqi J Pharm Sci 2011;20:70-80.

9. Kale SS, Viraj SS, Prajkta L, Ughade, DT. Baviskar bilayer tablet. Review article. Int J Pharm Sci Rev Res 2011;9:2-5. 
10. Dixit N. Floating drug delivery system. J Curr Pharm Res 2011;7:6-20.

11. Sowmya C, Reddy SC, Tabasum SG, Varma V. An overview on bi-layer tablets. Int J Pharm Technol 2012;4:2143-56.

12. Parashar T, Soniya, Vishal S, Gaurav S, Satyanan T, Chirag P, et al. Novel oral sustained release technology: A concise review. Int J Res Dev Pharm Life Sci 2013;2:262-9.

13. Jadhav P, Samnani A, Panday G, Dubey BK. Formulation and evaluation of simvastatin sustained release bilayer tablet using hydrophillic and or hydrophobic polymers. World J Pharm Pharm Sci 2012;1:621-32.

14. Yadav A, Jain KD. Formulation development and in vitro characterization of bilayer and floating- bioadhesive tablets of propranolol hydrochloride. Asian J Pharm Life Sci 2011;1:1-12.

15. Jain J, Mittal RP, Patel M. Formulation and evaluation of indomethacin bilayer sustained release tablets. Int J Pharmtech Res 2011;3:1132-8.

16. Jabbar MS, Khalil I. Formulation of metoprolol bilayer tablets as an oral modified release dosage form. Iraqi J Pharm Sci 2010;19:21-30.

17. Ranch KM, Koli AR, Vyas A, Parikh RK. Formulation, design and optimization of orodispersible tablets of atenolol. Int J Pharmtech Res 2009;1:1559-63.

18. Karwa P, Kasture V. Formulation and in vitro evaluation of bilayer tablets of zolpidem tartrate for biphasic drug release. Int J Pharmtech Res 2011;3:1919-29.

19. Patel SJ, Thakkar P, Patel K, Patel JK. A review on bilayer tablets. J Drug Discov Ther 2013;1:40-8.

20. Roy SK, Naskar S, Kundu S, Koutsu K. Formulation and evaluation of sustained release bilayer tablets of propranolol hydrochloride. Int J Pharm Pharm Sci 2015;7:264-9.

21. Shinde AJ, Misale GM, Salokhe SV. Development and evaluation of bilayer mucoahesive gastroretentive tablet of diltiazem hydrochloride. Int J Pharm Pharm Sci 2014;6:365-70. 